\title{
Functional products and preparations in the systemic concept of health
}

\section{Mykola Oseiko ${ }^{1}$, Vasyl Shevchyk ${ }^{2}$, Tetiana Romanovska ${ }^{1}$}

\author{
1 - National University of Food Technology, Kyiv, Ukraine \\ 2 - Chernigiv Regional Clinical Hospital, Chernigiv, Ukraine
}

Keywords:

KTIOL

Functional

Products

Oil

Health

Article history:

Received

12.09.2017

Received in revised

form 27.11.2017

Accepted 29.12.2017

Corresponding

author:

Mykola Oseiko

E-mail:

nikios@ukr.net

DOI:

$10.24263 / 2304-$

974X-2017-6-4-7

\section{Abstract}

Introduction. The analytical and experimental researches on the scientific substantiation of functional products and preparations in the new systemic concept of health have been carried out.

Materials and methods. Sunflower and linseed oil, oil compositions and products, antioxidants, unsaturated fatty acids, the role of cholesterol, the systemic concept of health. were researched. The kinetics of oxidation of oils at temperature processing characterized the average rate of change in their indexes (peroxide and acid numbers). Chromatographic method was used to evaluate volatile compounds.

Results and discussion. According to research results of the role of polyunsaturated fatty acids of omega- 3 and omega- 6 in vegetable oils and functional products and the problem of cholesterol in the life and health of people of different age groups it was suggestion the physiological-functional system of CTIOL, which is an integrated choice of factors in individual prevention, treatment and rehabilitation.

It was found that KTIOL-BF (1\%) reduces the average oxidation rate of sunflower oil at $150{ }^{\circ} \mathrm{C}$ ( 3 hours) in 12.2 times, at $200{ }^{\circ} \mathrm{C}$ (6 hours) in 13.6 times, the average acidity of the oil decreases by 9 and 2.2 times respectively. It was established that under similar conditions the average rate of oxidation of linseed oil decreases by 1.4 and 1.5 times, respectively. Acidity of oil practically does not decrease. It has been found that KTIOL-LS2 oil with 1\% KTIOL-BF at 20-25 ${ }^{\circ} \mathrm{C}$ is stored for 6 months. By component composition mayonnaise without cholesterol and lactose belongs to the diet group.

On the basis of the analysis of the gas chromatographic profiles of the oilseed composition KTIOL-LS2, it was is expressed a hypothesis concerning the possible reduction of the amount of volatile compounds in it, both due to the composition of the oil, and through the interaction of individual volatile ingredients.

Conclusions. Special products which are based on sunflower and linen compositions KTIOL-LS2 improve the physiological state of people of different age groups for the occurrence of disease-related and concomitant pathologies. 


\section{Introduction}

In today's ecological, economic and social conditions, as before, the problem of health and healthy lifestyle is topical. After all, most people understand that products and preparations (biologically active additives) should not only be tasty, but functional and safe.

The design and manufacture of safe and competitive functional products and preparations (FPP) on the world market and, in East Europe, are in demand. In particular, in Japan, the European Union and the United States, especially in the context of public health, a healthy, creative and active lifestyle.

The etiology and pathogenetic links of the development of major age and concomitant diseases, such as ophthalmologic (macular degeneration, glaucoma, cataract, etc.), are still not fully studied, and hence the absence of highly effective therapeutic and prophylactic products and preparations, methods and techniques [1].

As of 2005, in East European citizen the older people were diagnosed with a deterioration in health (a deficit and imbalance in the diet of many biologically active nutrients). The conclusion was reached on the urgency of developing scientific approaches to the creation of functional products. Products with a pronounced biological effect on the human body by type of substitution therapy [2].

According to a study conducted by the World Health Organization (WHO), around 600 million people in the world each year suffer from illnesses caused by poor quality food.

According to E.I. Chazova, depending on the age of a person, his way of life, nutrition and the state of the environment, its organisms at one time or another, resists the infection. That is, the process is gradually and in the first years asymptomatic. Some signs arise when the infection transits the bar of counteraction to the human immune system and begins the active destruction of body tissues. From classical prevention, he advises to lead a healthy lifestyle [3].

In the complex environmental, economic and social conditions of today, scientific substantiation of the technologies of functional products and preparations (FPP) of the special and ophthalmologic direction and the improvement of the concept of health ecology in relation to prevention, treatment and rehabilitation of a person is necessary.

By definition, WHO "Health is a state of complete physical, mental and social wellbeing." According to the Ministry of Health of Ukraine, the health of the population depends on the lifestyle, including nutrition (by 50-70\%), the level of development of the health care system (by 10-15\%), heredity (by 10-15\%), and from the environmental situation (10-20\%). Official statistics also indicate that there are serious problems in the health of the population (about $80 \%$ have a pathology, $48-60 \%$ overweight, etc.).

Modern changes in the science of nutrition and food technology are associated with the emergence of a new variety of food products, in particular physiologically functional, or shortened FPP. FPP is a food product that, in addition to its nutritional properties, has the ability to influence individual functions of the body, thereby reducing the risk of chronic diseases for their regular use [4]. Production of FPP in the leading countries is due to the general aging of the population. In addition, anthropogenic pressure on the environment is increasing, which also negatively affects the health of all segments of the population, regardless of age and social status.

In recent years, food for specific nutritional uses has become more and more confident with Food for Specific Health Use. The difference of these products from their traditional counterparts is that they not only have certain nutritional properties, but also have a purposeful effect on the functional activity of individual organs, systems and the organism as a whole, stimulating their capacity for work with a specific preventive and therapeutic 
and recreational purpose. In 1991, the concept of functional nutrition was developed in Japan, which was reflected in the special government order "On foods for special nutrition" (FOSHU).

Nicberg I.I. notes that even in scientific literature and in official documents, there is no unity in the definition of concepts relating to FPP and their scope [5]. And although in some cases they are positioned as food products (different from biological additives and proprietary drugs), others, on the contrary, indicate that they are most useful bioadditives or other therapeutic and prophylactic preparations. Although one of the significant distinctive characteristics of foods related to functional nutrition, according to pioneers of the definition of FPPs and their followers, is that they are not considered as medicinal substances. But there are many supporters of a different point of view. They believe that many products of functional nutrition are now in the area between preparations and food. Therefore, they can be attributed to foodstuffs themselves, as well as to their dietary varieties or even to medical preparations

The Australian National Center for Excellence in Functional Products (NCEFF) has defined these products: "Functional products are products that support the health and wellbeing of humans, providing health benefits against basic nutrition." The Australian market has a large number of availableFPP. These are dairy products, probiotics, omega-3 fatty acid products, cereal foods with supplementary food fibers, margarine with plant sterols, low blood cholesterol, products with low glycemic index, etc. According to Nickberg II more than $20 \%$ of the population have elevated cholesterol levels, which prompts them to give preference to FPP in order to reduce the risk of cardiovascular disease. According to Australian experts, reducing cholesterol by $10 \%$ may reduce the risk of heart disease by $25 \%$ or more [5].

In the system of complex modern technologies KTIOL $®$ for solution of the problem are used: integrated technologies, engineering, equipment, lines. It allows to carry out projects ranging from ideas, innovations, know-how and to the organization of production of high-quality and competitive products with functional properties $[6,7]$. In the difficult conditions of the present, the problem of the design and use of FPP, the relationship of the endoecology of the individual with the environment, the way of life and human health in Ukraine is relevant.

The most important problem in a market economy, in particular, in the WOT and the EU, is the introduction of innovative technologies and the organization of production. This will ensure the production of export and import of substitute products in accordance with modern requirements of safety, quality, competitiveness, functional and nutritional value [6-8].

Common oils (sunflower, soya, rapeseed, palm, etc.) do not have the optimum fatty acid and ingredient composition and do not suit many consumers in their characteristics [6, 9].

In order to obtain complete natural oils of functional and well-being purposes with a balanced biochemical composition, it is necessary that they have not been modified yet. Such oils and oleaginous products are not only products with a good price-quality ratio (the main criterion for market success), but also products that meet the specific needs of consumers for the prevention and treatment of chronic diseases.

Natural and composite oils are the suppliers of functional ingredients that have the potential to cause (due to their systematic consumption) a beneficial effect on the physiological functions and metabolism of the human body. The group of physiologically functional ingredients in oils and fats include polyunsaturated fatty acids (PUFAs), medium chain fatty acids, fat-soluble vitamins and biologically active substances (BAS). The main 
group of functional ingredients is a linear structure PUFA with a paired number of carbon atoms (from $\mathrm{C} 18$ to $\mathrm{C} 24$ ) cis configuration. Linoleum, linolenic and arachidonic acids are essential acids, the lack or lack of which in food negatively affects the human body. Vegetables, including linseed, hemp, corn, sunflower, rapeseed, and soya, serve as the main food source of linoleic and linolenic acid.

In the human body, omega-3 PUFAs are included in the lipid double layer of cell membranes, regulating their properties in the composition of phospholipids of membranes. They also contribute to the metabolism of cholesterol in the liver and its elimination from the body. Due to the lack of omega-3 PUFAs, their place is occupied by omega-6 PUFAs delivered from food.

The reduction in cholesterol content is also facilitated by the presence of lipids in the fatty diet, which include acyl carboxylic acids with an average chain length of 6 to 10 carbon atoms. The effectiveness of the physiological action of PUFA depends on the number and ratio of various acids coming from the food.

According to modern ideas in the diet of a healthy person, the ratio of omega- 6 and omega-3 PUFA should be 10: 1. For different pathological states, the ratio of these acids in the diet changes in the direction of increasing the proportion of linolenic acid and may reach 5: 1 and even 2: 1. The second group of functional ingredients in oils and oleaginous products is fat-soluble vitamins (A, D, E, K) and provitamin A ( $\beta$-carotene), whose consumption deficit is $40-60 \%$ and $20-30 \%$ respectively. An adequate level of consumption of fat-soluble vitamins can be guaranteed by the technological adoption of vitamins, which does not require significant changes in the hardware pattern of production. Oils and oilseeds, unlike traditional counterparts, should contain PUFA and fat-soluble vitamins that relate to an adequate level of their intake and meet the physiological needs of the body in these ingredients.

It should be noted that one of the directions of designing the functional properties of oils, oil products and preparations is the use of composite oils for food production: emulsion, milk, diet, special, baby food products, etc. - with the necessary content and ratio of acids omega- 6 and omega- 3 [10-13].

PUFAs of the family of omega- 3 as part of cell membranes determine their functions and participate in the transformation of signals from the environment. This leads to a change in cellular metabolism. Membrane enzymes, interacting with acids omega-3, exhibit biochemical activity. This is of particular importance in tissues with high electrophysiological activity, for example, in brain tissues or retina of the eye [14].

The oils obtained from mixtures of flaxseed, sesame and thistle seeds have a balanced fatty acid composition according to the ratio of omega-6/omega-3 fatty acids; contain in a favorable ratio gamma - and alpha-tocopherols; have high antiradical activity and are resistant to oxidative changes during storage. On the basis of the comparative analysis, it was concluded that the oils obtained by pressing the mixture of seeds (flax, sesame and thistle) have advantages over the compositions made by mixing the corresponding oils. First, this technology allows one to get the oil in one step, while for the oil mixture, the desired oils are first obtained, and then the composition is prepared, which can lead to an increase in the peroxide number. Secondly, the natural composition of the minor components contributes to increasing the resistance to oxidative changes during storage at room temperature [15]. There is also an opportunity for the recovery of oils (fats) after technological, temperature and/or adsorption processing [15-17].

Cholesterol (CS) plays an important role in the life processes of the body, as it participates in various biochemical processes. In healthy people, the level of cholesterol is usually maintained at a certain constant level. But under the influence of harmful factors, in 
particular, long-term disorders of eating behavior, chronic diseases, age-related hormonal changes, etc., the body undergoes a violation of lipid metabolism with an increase in the level of cholesterol in the blood. Elevated levels of CS and other lipid metabolism disorders are a risk factor and one of the causes of cardiovascular and other diseases. It should be noted that in the diet of Ukrainians mainly sunflower oil is used. Other oils are rape, soya beans, mustard, hemp, coriander, olive, and the like.

Diseases caused by acid deficiency of omega-3s include obesity, arrhythmia, hypertension, atherosclerosis, diabetes, and the like. That is why during the last two decades, the acids of omega- 3 are the subject of close attention of researchers $[6,18]$.

Indicator of information content of general cholesterol is a blood test. Results of the complex study presented in the review [17]. They indicate a lack of information on the level of general X-ray in the blood as an indicator of the atherosclerotic process, its progression, and the need for a more in-depth analysis of atherogenesis factors to assess the risk of developing coronary heart disease and the effectiveness of the therapy being performed.

An elevated blood cholesterol level is considered a key risk factor for developing cardiovascular disease and stroke, two of the world's leading killers in the United States. Saturated fat, mainly in meat, poultry, raw and other products of animal origin, is the main driving force of raising the level of cholesterol in the blood.

Studies in recent years have confirmed the decrease in blood cholesterol by up to $35 \%$ (from the original) for the use of a plant diet. In many cases, such a decrease corresponds to the result with the use of medication, but without negative side effects. People who need drugs to lower the level of cholesterol to prevent cardiovascular disease can only achieve this with the use of a plant diet. In general, a herbal diet lowers blood cholesterol levels due to the fact that this diet contains unsaturated fats and zero cholesterol. Moreover, the plant diet is rich in fiber, which in turn also reduces the level of cholesterol. Soy also reduces the level of X-rays from those who include it in their diet.

It should be noted that deserving attention of scientists, physicists, chemists, nutritionists and technologists discussing the importance of and influence of CS on the body of people of different age groups. Thus, the article [20] emphasizes the need to consider the inadequate functioning of the thyroid gland and eliminate the use of "dense" carbohydrates (sweet, rich starch, refined food).

Today, emphasis in gerontology is aimed at prolonging the very active lifestyle and long-term capacity of a person. In principle, you can immerse any conscious person in the state of active longevity and the health of the environment. Taking into account the data of the analytical review of scientific sources $[2,4,5,13,18,21]$ and the results of own research of FPP it is expedient to determine the system and innovative concept of prevention, treatment and rehabilitation of patients with ophthalmologic and concomitant diseases.

\section{Materials and methods}

It were researched: scientific and practical substantiation of the concept of ecology of health in the system of KTIOL for ophthalmological and gerontological practice, antioxidant resistance of oils to preparations and the creation of FPP KTIOL (without cholesterol and lactose).

The research was carried out using sunflower oil and linseed oil. Experimental samples of oil compositions were prepared by mixing the original oils at a given ratio at room 
temperature. The obtained KTIOL oil compositions were stored in the refrigerator at a temperature of 4 to $6{ }^{\circ} \mathrm{C}$. Highly temperature treatment of samples in time is made using KTIOL preparations. The kinetics of oxidation of each sample of oil characterized the average rate of change in their indexes (peroxide and acid numbers) during the experiment.

Chromatographic method was used for qualitative evaluation of volatile compounds of the original oils and functional oil composition of KTIOL [6].

\section{Results and discussion}

\section{Systemic concept of ecology of health}

Knowing the key health factors, it is possible to identify the problem at an early stage of its occurrence. For example, it is important for everyone to know and control such indicators as body mass index, blood pressure, level and types of cholesterol in the blood, state of the visual system, etc. Unfortunately, a significant part of people do not know what indicators can be considered normal and how to normalize and maintain them rationally. In the conception of the ecology of health, the keys are the systems of KTIOL.

They include:

- $\quad$ scientific and practical substantiation of safe functional, special and gerontological products and preparations on micro and nano-level (system KTIOL-I);

- a complex of scientific and practical measures aimed at the improvement of the personality and endoecology of health (system KTIOL-II) for maintenance of safe human life.

The ecological and technological system of KTIOL-I (Complex Technologies of Engineering, Equipment, Lines) was first aimed at the synthesis of special products with a nanostructure for high pressures. Key provisions of the system KTIOL-I:

1. Maintenance of the structure of the product (preparation) on the micro and nanolevel;

2. Ecological and economic efficiency;

3. System approach to the techno methodology concerning the self-realization of the personality in the technologies of production and therapy of safe food, pharmaceutical, cosmetic products and preparations.

The health-therapeutic (physiological-functional) system of KTIOL-II (Integrated Therapy of Individual Health Improvement of People) is based on the analysis of the quality and safety of water, food products and drugs (dietary, biologically active additives), environmental and endoecological aspects of personal health. The KTIOL-II system as a basic component (key words) includes: hygiene of thoughts (positive thinking); prevention (individual, periodic, instrumental); safe water, healing; breathing health, curative; nutrition health and medical (products and preparations); load physical, individual, selective (walking, swimming, yoga, etc.); massage (general, local, biologically active points); meditation (healing mood); sleep health-therapeutic and so on.

It should be noted that now in the concept of wellness nutrition it is observed a priority tendency to increase in the diet of oils with high content of PUFAs omega-3 and the development of oils compositions with the optimal ratio of acids omega-3/omega- 6 for consumers of different age groups $[6,7,19]$.

Accelerated methods for determining the stability and shelf life of edible vegetable oils assume oxidation at elevated temperatures. It is known that due to different oxidation routes, the proportion between the rates of accumulation of primary and secondary 
oxidation products in vegetable oils is different and stored up to $80^{\circ} \mathrm{C}$. Oxidation of oils at higher temperatures is accompanied by a violation of proportionality. Therefore, it is necessary to confirm the compliance of the indicators at the temperature used and under standard stage conditions.

\section{Oxidation of sunflower and flaxseed oil with KTIOL preparations}

Since the oxidation of vegetable oils is a complicated multistage process in which simultaneously many reactions occur, differing in speed, direction and sequence $[6,15,22]$, the establishment of temperature dependence was carried out empirically on the basis of long experiments.

Experimentally, the effect of three KTIOL preparations at a dose of $0.5 \%$ on the resistance to oxidation of sunflower oil was determined by heating at a temperature of 200 ${ }^{\circ} \mathrm{C}$ and a duration of 3 hours (Table 1). For antioxidant action, KTIOL-BF was taken for further investigation.

Indicators of the preparation KTIOL-BF: mass fraction of moisture and volatile substances $-2.5 \%$, water-retaining ability $-40.2 \%$, oil-retaining ability $-22.5 \%$, granulometric composition: fraction up to $0.25 \mathrm{~mm}-45 \%, 0.25-1 \mathrm{~mm}-34 \%$. $1-2 \mathrm{~mm}-$ $21 \%$. It should be noted that the index of oil retention capacity of the preparations KTIOL$\mathrm{BF}$ is smaller than the imported preparations Tonsil - $312(34 \%)$.

Table 1

Influence of KTIOL preparations on the resistance of sunflower oil to oxidation during heating

\begin{tabular}{|l|c|c|c|c|}
\hline \multirow{2}{*}{ Indicator } & \multicolumn{4}{|c|}{ Preparations } \\
\cline { 2 - 5 } & $\begin{array}{c}\text { KTIOL- } \\
\text { 1NL }\end{array}$ & KTIOL-CF & KTIOL-BF & $\begin{array}{c}\text { Control } \\
\text { (oil) }\end{array}$ \\
\hline Peroxide number, & & & & \\
mmol 1/2 O/kg: & $\mathbf{4 , 2}$ & $\mathbf{3 , 4}$ & $\mathbf{3 , 9}$ & $\mathbf{1 , 5}$ \\
before heating up & $\mathbf{7 , 3}$ & $\mathbf{4 , 4}$ & $\mathbf{4 , 1}$ & $\mathbf{8 , 9}$ \\
after heating & & & & \\
\hline Acid number, mg & $\mathbf{1 , 8}$ & $\mathbf{0 , 7}$ & $\mathbf{0 , 5}$ & $\mathbf{2 , 7}$ \\
KOH/g & $\mathbf{2 , 7}$ & $\mathbf{3 , 0}$ & $\mathbf{2 , 2}$ & $\mathbf{3 , 2}$ \\
before heating up & & & \\
after heating/
\end{tabular}

The kinetics of oxidation of oils was characterized by an average rate of change in the parameters for the duration of the experiment.

Increased temperature treatment of sunflower and linseed oil and the dosage of KTIOL was studied to determine the average oxidation velocity (VO) and acidity (VA) of the oil.The initial peroxide number of sunflower oil is $4.25 \mathrm{mmol} 1 / 2 \mathrm{O} / \mathrm{kg}$, the initial amount of acid oil is $0.47 \mathrm{mg} \mathrm{KOH} / \mathrm{g}$. The data is presented in Tables 2 and 3, respectively.

It was found (Table 2 and 3 ) that the use of the KTIOL-BF preparation at a dose of $1 \%$ reduces the average oxidation rate of sunflower oil at $150{ }^{\circ} \mathrm{C}$ ( 3 hours) by 12.2 times at 200 ${ }^{\circ} \mathrm{C}$ (6 hours at 13.6 times. The average rate of acidity of sunflower oil decreases at $150{ }^{\circ} \mathrm{C}$ (3 hours) 9 times, at $200{ }^{\circ} \mathrm{C}$ ( 6 hours) 2.2 times.

Average velocity of oxidation (VO) and acidity (VA) of linseed oil is determined by the preparation of KTIOL - BF at high temperature in time. The initial peroxide value of 
the oil is $4.4 \mathrm{mmoles} 1 / 2 \mathrm{O} / \mathrm{kg}$, the initial acid number is $1.49 \mathrm{mg} \mathrm{KOH} / \mathrm{g}$. The data is presented in slabs 4 and 5, respectively.

Table 2

Effect of the dose of the preparation of KTIOL-BF, temperature and duration of processing sunflower oil on the average rate of its oxidation (VO)

\begin{tabular}{|c|c|c|c|c|c|}
\hline \multirow{2}{*}{$\mathbf{N}$} & \multirow{2}{*}{$\begin{array}{c}\text { Preparation } \\
\text { dose, \% }\end{array}$} & \multicolumn{5}{|c|}{ Temperature, ${ }^{\circ} \mathbf{C}$} \\
\cline { 3 - 6 } & \multirow{2}{*}{} & \multicolumn{4}{|c|}{$\mathbf{1 5 0}$} \\
\cline { 3 - 6 } & & \multicolumn{5}{|c|}{$\mathbf{2 0 0}$} \\
\cline { 3 - 6 } & & $\mathbf{3}$ & $\mathbf{4}$ & $\mathbf{3}$ & $\mathbf{3}$ \\
\cline { 3 - 6 } & & 0,98 & 1,31 & 1,92 & 1,64 \\
\hline 1 & 0 & 0,34 & 0,25 & 0,40 & 0,75 \\
\hline 2 & 0.25 & 0,40 & 0,33 & 0,47 & 0,22 \\
\hline 3 & 0,5 & 0,08 & 0,12 & 0,15 & 0,12 \\
\hline 4 & 1,0 & 0,13 & 0,17 & 0,20 & 0,33 \\
\hline 5 & 1,5 & 0,34 & 0,25 & 0,41 & 0,75 \\
\hline 6 & 2,0 & &
\end{tabular}

Table 3

Effect of the dose of the preparation of KTIOL-BF, temperature and duration of sunflower oil processing on the average rate of its acidity (VA)

\begin{tabular}{|c|c|c|c|c|c|}
\hline \multirow[t]{5}{*}{$\mathbf{N}$} & \multirow{5}{*}{$\begin{array}{c}\text { Preparation } \\
\text { dose, } \%\end{array}$} & \multicolumn{4}{|c|}{ Temperature, ${ }^{\circ} \mathrm{C}$} \\
\hline & & \multicolumn{2}{|c|}{150} & \multicolumn{2}{|c|}{200} \\
\hline & & \multicolumn{4}{|c|}{ Processing time, $h$} \\
\hline & & 3 & 6 & 3 & 6 \\
\hline & & \multicolumn{4}{|c|}{ Average rate of increase in acidity, VA } \\
\hline 1 & 0 & 0,09 & 0,16 & 0,07 & 0,11 \\
\hline 2 & 0,25 & 0,06 & 0,09 & 0,05 & 0,10 \\
\hline 3 & 0,5 & 0,04 & 0,07 & 0,03 & 0,09 \\
\hline 4 & 1,0 & 0,01 & 0,03 & 0,01 & 0,05 \\
\hline 5 & 1,5 & 0,01 & 0,05 & 0,00 & 0,06 \\
\hline 6 & 2,0 & 0,06 & 0,09 & 0,05 & 0,11 \\
\hline
\end{tabular}

Table 4

Effect of the dose of the preparation of KTIOL-BF, temperature and duration of treatment of linseed oil on the average rate of its oxidation (VO)

\begin{tabular}{|c|c|c|c|c|c|}
\hline \multirow[t]{5}{*}{$\mathbf{N}$} & \multirow{5}{*}{$\begin{array}{l}\text { Preparation } \\
\text { dose, } \%\end{array}$} & \multicolumn{4}{|c|}{ Temperature, ${ }^{\circ} \mathrm{C}$} \\
\hline & & \multicolumn{2}{|c|}{150} & \multicolumn{2}{|c|}{200} \\
\hline & & \multicolumn{4}{|c|}{ Processing time, $h$} \\
\hline & & 3 & 6 & 3 & 6 \\
\hline & & \multicolumn{4}{|c|}{ Average rate of oxidation, VO } \\
\hline 1 & 0 & 1,95 & 2,43 & 2,57 & 1,80 \\
\hline 2 & 0,5 & 1,45 & 2,11 & 2,45 & 1,50 \\
\hline 3 & 1,0 & 1,35 & 1,93 & 2,18 & 1,18 \\
\hline 4 & 2,0 & 1,38 & 1,95 & 2,34 & 1,30 \\
\hline
\end{tabular}


Table 5

Effect of the dose of the preparation of KTIOL-BF, temperature and length of processing of linseed oil on the average rate of its acidity (VK)

\begin{tabular}{|c|c|c|c|c|c|}
\hline \multirow[t]{5}{*}{$\mathbf{N}$} & \multirow{5}{*}{$\begin{array}{c}\text { Preparation } \\
\text { dose, } \%\end{array}$} & \multicolumn{4}{|c|}{ Temperature, ${ }^{\circ} \mathrm{C}$} \\
\hline & & \multicolumn{2}{|c|}{150} & \multicolumn{2}{|c|}{200} \\
\hline & & \multicolumn{4}{|c|}{ Processing time, $h$} \\
\hline & & 3 & 6 & 3 & 6 \\
\hline & & \multicolumn{4}{|c|}{ Average rate of increase in acidity, VA } \\
\hline 1 & 0 & 1,17 & 0,86 & 1,83 & 1,28 \\
\hline 2 & 0,5 & 1,09 & 0,79 & 1,73 & 1.04 \\
\hline 3 & 1,0 & 1,04 & 0,72 & 1,50 & 0,96 \\
\hline 4 & 2,0 & 1,05 & 0,78 & 1,65 & 1,01 \\
\hline
\end{tabular}

It was found (Table 4 and 5) that the use of KTIOL-BF in a dose of $1 \%$ reduces the average rate of oxidation of flaxseed oil at $150{ }^{\circ} \mathrm{C}(3$ hours $) 1.4$ times, at $200{ }^{\circ} \mathrm{C}(6$ hours $)$ 1.5 times. The average rate of acidity of flaxseed oil decreases at $150{ }^{\circ} \mathrm{C}$ ( 3 hours) by 1.1 times, at $200{ }^{\circ} \mathrm{C}$ ( 6 hours) by 1.3 times.

The data obtained are used by us when the FPD is conserved on the basis of vegetable oils, fats and their compositions. Further study requires the direction of selective treatment of lipid-containing plant material, FPP prophylactic, therapeutic and rehabilitation purposes.

\section{Justification the sensory properties of oil composition}

On the basis of the data obtained for the production of the oil composition, sunflower oil and linseed oil was taken [6, 20, 21]. Sunflower-refined oil was used as the basis for the oil-based composition of KTIOL. Oils with omega-3 fatty acids - linen for the first cold spin. According to sensory properties parameters, the content of vitamin E and fatty acids of omega-3 ( $\omega-3)$ is better recognized as the composition of KTIOL-LS2. Characteristic of KITOL-LS2 composite oil: color - bright yellow; smell - inherent to this composition without the construction, almost not noticeable; taste - inherent composition without a posteriori, not expressed; the content of omega-3 fatty acids $(\omega-3), \%-11.1$; the content of omega- 6 fatty acids $(\omega-6), \%-22.9$; ratio of omega-3 fatty acids to omega-6 ( $\omega-3: \omega-6)-$ $1: 2$; The content of vitamin $\mathrm{E}$ is $72.4 \mathrm{mg} \%$.

\section{Gas chromatographic researches results}

Gas chromatographic method was used to evaluate the volatile compounds of the original oils and the functional composition oil KTIOL-LS2 [6]. Chromatograms are shown in Figure 1-3. From the data analysis of Figure 1-3 found the following:

1. Volatile compounds of sunflower oil are distributed in the time interval of 10-35 minutes. at maximum signal altitude 90 ;

2. Volatile compounds of linseed oil are distributed in the time interval of 20-35 minutes. at maximum signal altitude 50;

3. Volatile compounds of composite oil KTIOL-LS2 are distributed in the time interval of 10-35 minutes at maximum signal strength 40 . The hypothesis concerning the possible reduction of the volatile compounds of KTIOL-LS2 composite oil, both due to the composition of the oil, and through the interaction of individual volatile ingredients, is expressed. 


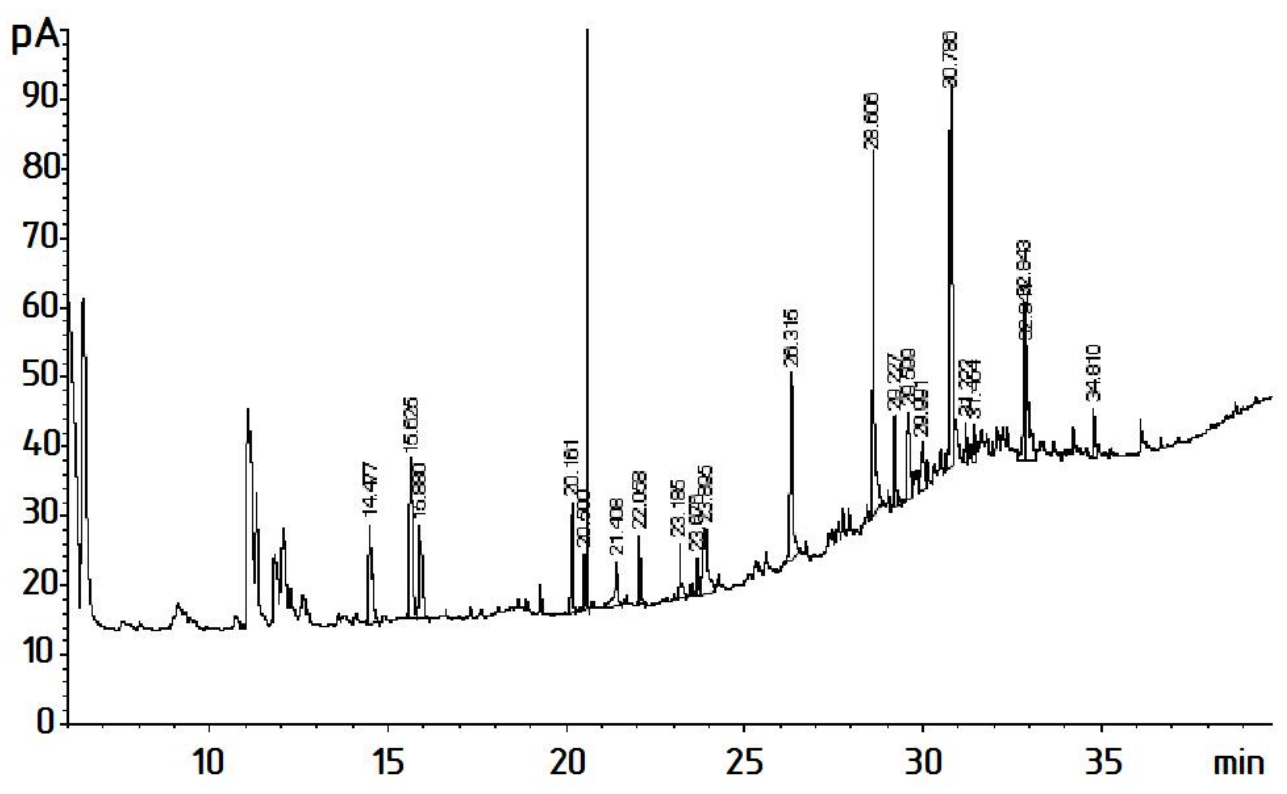

Figure 1. Chromatographic profile of volatile compounds of sunflower oil

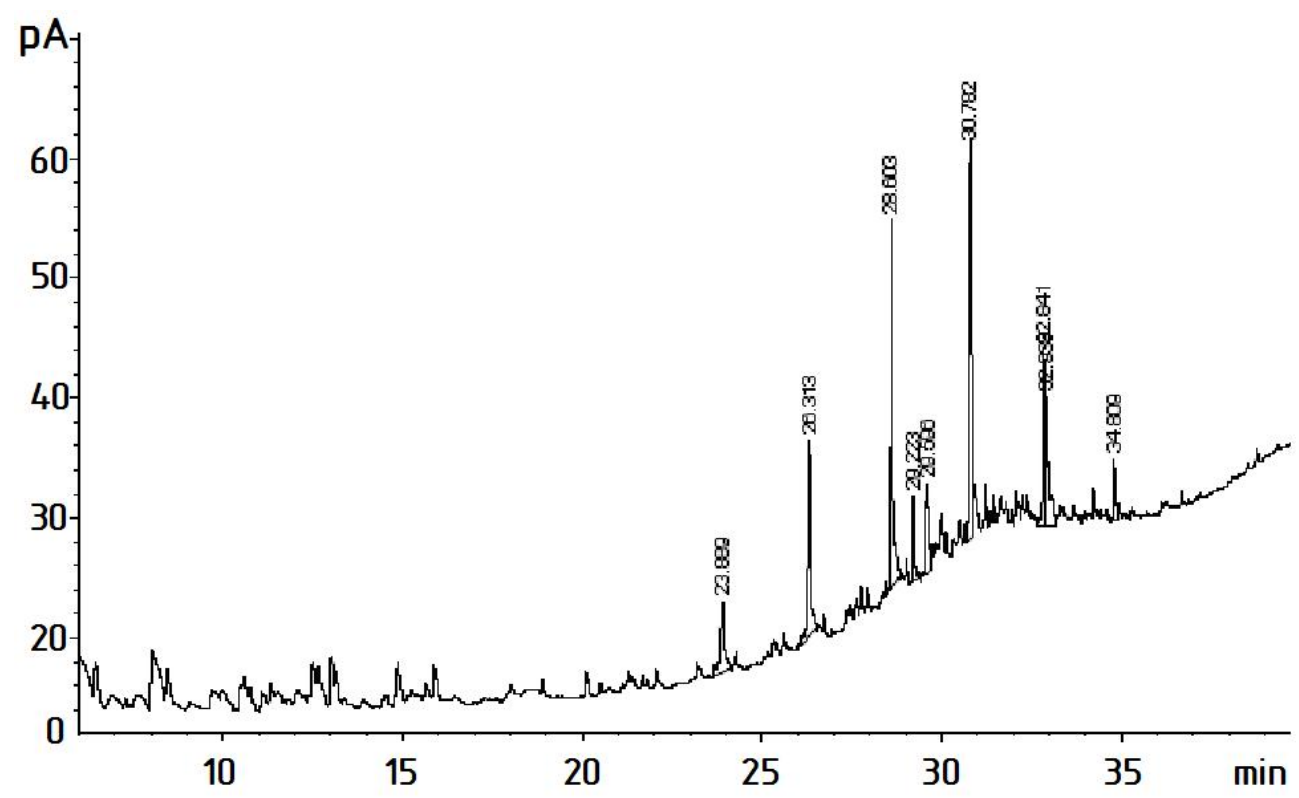

Figure 2. Chromatographic profile of volatile compounds of the original linseed oil 


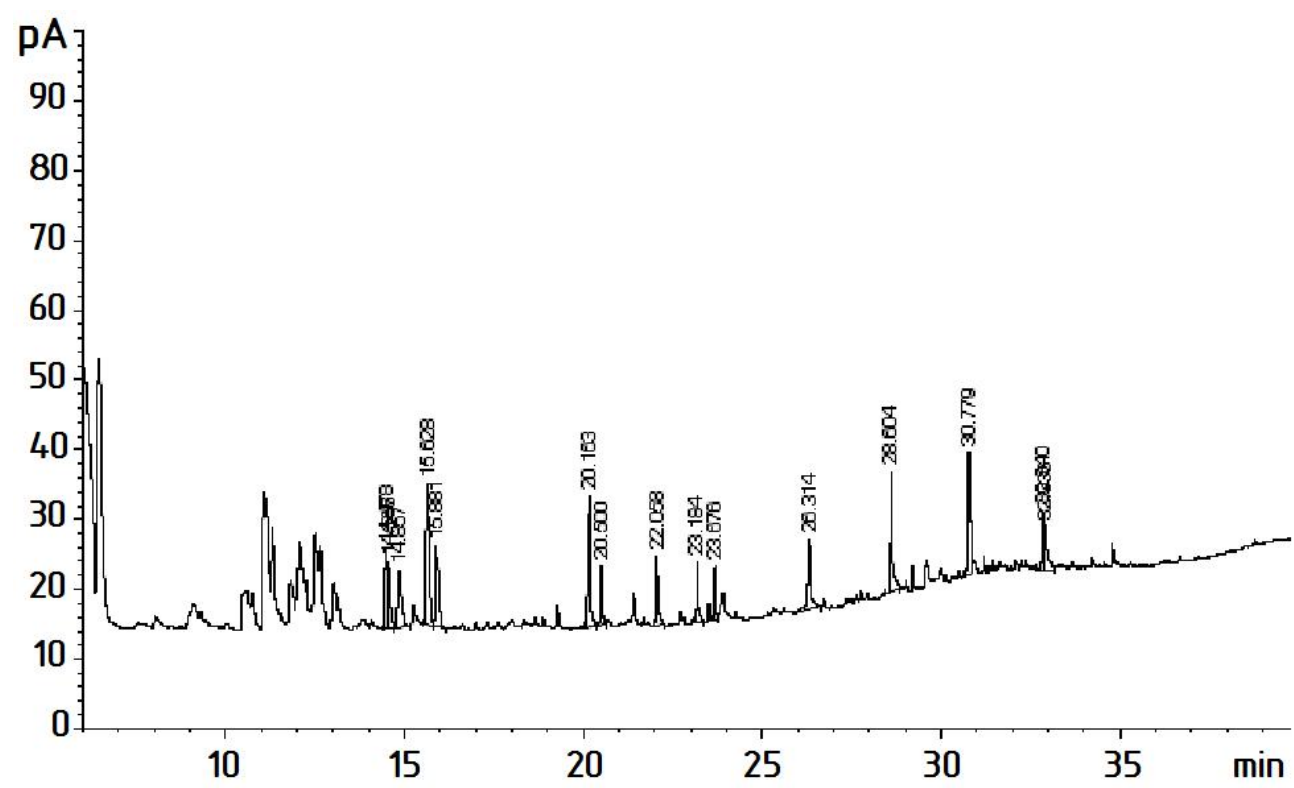

Figure 3. Chromatographic profile of volatile compounds of composite oil KTIOL-LS2

The developed composition oil KTIOL-LS2 it is expedient to use as a functional product or as a preparation of sanitary-and-therapeutic action and as a part of oily-fat emulsion systems. The presence of volatile compounds in the oil-and-oil system (oils, compositions, etc.) is associated with oxidation processes and the content of primary and secondary oxidation products of unsaturated acylglycerols and fatty acids.

Reducing the content of oxidation products in the oil-and-fat system indicates the neutralization and/or inhibition of oxidation processes.

It is noted that KTIOL-LS2 composite oil with $1 \%$ of the preparation KTIOL-BF according to the complex index of oxidation resistance (acid number $\leq 1.5$, peroxide number $\leq 10$ ) is stored at $20-25{ }^{\circ} \mathrm{C}$ for 6 months.

\section{Practical using of research resutls}

Based on the compositional oil of KTIOL-LS2, low-calorie mayonnaise with flavoring additives KTIOL-BIO was developed. In the formulation used the original component composition. The size of the particles of the system is brought to micro- and nanosize by repeated processing in a mixer.

The new technical solution is protected by a patent UA 086341U. By component composition, mayonnaise refers to a dietary assortment group whose emulsion products are manufactured using standard technology. The use of the new composition of mayonnaise KTIOL-BIO makes it possible to produce a stable, high-quality, safe low-calorie product with flavorless additives without cholesterol and lactose, with improved organoleptic and physico-chemical parameters. 


\section{Conclusions}

Creation of functional and special products and preparations that improve the physiological state of people of different age groups for the occurrence of disease and related pathologies, is an important area of the problem of ensuring active and creative life of the population.

The innovative concept includes the use of the KTIOL-II system for complex prevention and curing of ophthalmologic and concomitant diseases.

New data on the average oxidation rate and increase in the acidity of sunflower and linseed oils during their high temperature treatment up to $200{ }^{\circ} \mathrm{C}$ in time are obtained. It was established that the use of the preparation KTIOL-BF in a rational dose of $1 \%$ provides an increase in the antioxidant stability of the oils under study. The composition of the oilbased composition of KTIOl-SL2 for functional products of KTIOL of preventive and health-treatment action was substantiated.

On the basis of theoretical and experimental researches, a new functional product of KTIOL-BIO has been developed for use in cholesterol, lactoid and healing and therapeutic diets.

\section{References}

1. Oseiko N.I., Shevchyk V.I. (2015), Gerontological aspects of prevention of ophthalmic diseases in the system KTIOL II, Pharmacology, Pharmaceutical Technology and Pharmacotherapy in Active Longevity: book of abstracts of the II International Scientific Conference, OIHN, Vilnius, p. 46.

2. Grigorov Yu.G., Lymar A.A., Podrushnyak A.Ye., Voronov S.V. (2005), Funktsional'nyye produkty dlya lyudey starshe vozrastov, Problemy pitaniya, 2, pp. $27-31$.

3. Chazov Ye.I. (2015), Prichiny zabolevaniy, Available at: http://medinfo.ua/analitic/00015f9e254756fd9217ca04a919e51b.

4. Kaprel'yants L.V., Iorgachova K. I. (2003), Funktsional'nyye produkty, Pechat, Odesa.

5. Nikberg I.I. (2011), Functional foods in the structure of modern power, International Journal of Endocrinology, 6(38).

6. Oseyko M.I. (2006), Tekhnologiya rastitel'nykh masel, Varta, Kyiv.

7. Oseyko M.I. (2008), Gerodiyetichni produkty, BAD i geroprotektory v sisteme KTIOL, Molochnaya promyshlennost', 3, pp. 51-56.

8. D'yakonova A.K., Nesterenko V.V. (2014), Sovremennoye sostoyaniye i perspektivy razvitiya proizvodstva pishchevykh produktov gerodiyetichnogo naznacheniya, Pishchevaya nauka i tekhnologiya, ONAPT, 3 (28), pp. 3-8.

9. Vaisali C., Charanyaa S., Belur P.D. et. al. (2015), Refining of edible oils: a critical appraisal of current and potential technologies, International Journal of Food Science and Technology, 50(1), pp. 13-23.

10. Gusnstone F.D. (2002), Vegetable oils in food technology: composition, propertiesanduses, secondedition, Taylor \& Francis, Blackwell.

11. Ottavy P.B. (2010), Obogashcheniye pishchevykh produktov i biologicheski aktivnyye dobavki, Professiya, Sankt-Peterburg.

12. Smirnova Ye.A., Kochetkova A.A., Nikolayev I.V., Koroleva A.V. (2012), Biokhimicheskiye i fiziologicheskiye osobennosti polinenasyshchennykh zhirnykh 
kislot: perspektivy sozdaniya novykh funktsional'nykh pishchevykh produktov, Masla $i$ Zhiry, 5, pp. 8-11.

13. Samoylov A.V. (2013), Nutritsiologicheskiye i normativnyye aspekty razrobotki zhirovykh produktov funktsional'nogo naznacheniya, Masla $i$ Zhiry, 3-4, pp. 18-19.

14. Eidelman A.I. (2001), Infant Nutrition 2000, pp. 21-29.

15. Guseva D.A. (2010), Sravnitel'nyy analiz smesey masel iz semyan l'na, kunzhuta i rastoropshi, Maslozhirovaya promyshlennost', 6, pp. 29-34.

16. Wannahari R., Nordin M.F.N. (2012), Reduction of peroxide value in used palm oil using bagasse adsorbent, American International Journal of Contemporary Research, 2(1), pp. 185-191.

17. Sakulthaijaidee Nattaporn, Thamakorn Porjai (2015), Recovery of used frying palm oil by acidified ash from rice husk, Journal of Science and Agricultural Technology, 1(1), pp. 193-196.

18. Ipatova L.G., Kochetkova A.A., Nechayev A.P., Tutel'yan V.A. (2009), Zhirovyye produkty dlya zdorovogo pitaniya: sovremennyy vzglyad, DeLi print, Moscow.

19. Kovalenko V.N., Talayeva T.V., Bratus' V.V. (2009), Kholesterin, triglitseridy, narusheniya obmena lipoproteinov - patogeneticheskaya, diagnosticheskaya i prognosticheskaya znachimost' v aterogeneze, Zhurnal AMN Ukrainy, 15(4), pp. 685725.

20. Sineva O.I. (2016), Kholesterinovaya boynya, Preduprezhdeniye plyus. Ukraina, 2, pp. 20-23.

21. Shenderov B.A. (2003), Sovremennoye sostoyaniye i perspektivy razvitiya kontseptsii «funktsional'nogo pitaniya, Pishchevaya promyshlennost', 6, pp. 6-8.

22. Rudnik E., Szczucinska A., Gwardiak H. et. al. (2001), Comparative studies of oxidative stability of linseed oil, Thermochimica Acta, 370(1-2), p. 135-140.

23. Pal U.S., Patra R.K., Sahoo N.R. et. al. (2015), Effect of refining on quality and composition of sunflower oil, Journal of Food science and technology, 52(7), p. 4613461.

24. Smirnova Ye.A., Kochetkova A.A., Nikolayev I.V., Koroleva A.V. (2012), Biokhimicheskiye i fiziologicheskiye osobennosti polinenasyshchennykh zhirnykh kislot: perspektivy sozdaniya novykh funktsional'nykh pishchevykh produktov, Masla $i$ Zhiry, 6, pp. 11-13. 